\title{
Isolation of a Gram Negative Fish Pathogenfrom Moroccan Rainbow Trout Hatcheryin Winter and its Classical Characterization
}

\author{
Assia KRITIHI ${ }^{1,2,3^{*}}$, Khadija OUAISSA ${ }^{1}$, Abdelaziz MAYCHAL ${ }^{2}$,Younes \\ OUMESSAOUD $^{2}$, Mustapha BARAKATE ${ }^{3}$ and Mustapha HASNAOUI ${ }^{1}$
}

\author{
${ }^{1}$ Environmental Engineerig Team, Faculty of Sciences and Techniques, Sultan Moulay Slimane University. BO. 523. \\ M'Ghila, 23000 Beni Mellal. Morocco. \\ ${ }^{2}$ Ain Aghbal pisciculture Farm, Azrou. Morocco. \\ ${ }^{3}$ Laboratory of Biology and Biotechnology of Microorganisms, Faculty Semlalia of Sciences. \\ Cadi Ayyad University.Marrakech. Morocco. \\ Corresponding author*: Email:assiakritihi@g mail.com ； Phone number: +212674670753
}

\begin{abstract}
Salmonidaquaculture represents one of the most important fish groups in the aquaculture industry $(\underline{F A O}, 2016)$. However, the success and sustainability of salmonid aquaculture largely depend on disease control. Although Rainbow trout is relatively sensitive to diseases, several bacterial, viral and parasitic diseases have been reported.

However, only opportunistic pathogens whose infectivity is expressed by a decline in the fish conditions and of its natural defenses, linked to disturbances of the environment or livestock practices. Livestock is the most favorable context for the development of bacterial pathologies, that's why we have too many bacterial pathogenic species for fish; the most serious infections in our latitudes are Aeromonadaceae, Vibrionaceae, Enterobacteriaceae and Flavobacteriaceae (Noga 1996, Austin and Austin 1999, Woo and Bruno 1999).
\end{abstract}

Moroccan aquaculture has undergone a rapid development and expansion over the last decade, to this end, Rainbow trout (OnchorhyncusMykiss) have been maintained at AinAghbal Fish farm - Azrou-Morocco; for production, livestock and transformation activity and also for commercialization.

The most important bacterial freshwater pathogen affecting salmonid livestock in fish farms in Morocco is the cold-water disease as a result of affection by Flavobactriumpsychrophilum bacteria.

Our study aimed on approving the presence of this bacterium and to characterize it biochemically, enzymatically and also physiologically.

Keywords- Moroccan aquaculture, Rainbow trout, Flavobactriumpsychrophilum, bacterial pathologies, freshwater, characterization.

\section{INTRODUCTION}

The cumulative mortality rates due to bacterial infections were higher, fry syndrome, spine deformities, darkening of skin color, and hemorrhages were observed in larvae after hatching, so, the present study was undertaken to investigate the presence of pathogenic bacteria in eggs in order to control the effects of bacterial contamination on the performance of the early stages of trout grown in hatchery systems, and also in juvenile stage. Bacterial, fungal, viral and parasitic diseases have been commonly reported from both wild and reared aquatic systems all over the world (Noga 1996) and they presentedcrucial considerations for trout production in hatchery systems. Infections result in a high fish morbidity and/or mortality, marketing problems, and associated economic losses (Austin and Austin 2007).

Although Rainbow trout is relatively sensitive to diseases, several bacterial, viral and parasitic diseases have been reported worldwide including Yersiniosis, Furunculosis, Columnaris disease, BCWD and RTFS.

The genus Flavobacterium was described for the first time in (1923) by Bergey et al.The taxonomic position of this bacterium has changed considerably over the past years, and ithas been variously designated as Flexibactersychrophilusand Cytophagapsychrophila, the most recent positioning being Flavobacterium psychrophilum (Bernardet et al. 1996).

Flavobacteium psychrophilum witch is a widely distributed Gram negative bacterium, belonging to this genus,produces an acute septicaemic infection in juveniles and named rainbow trout fry syndrome (RTFS) while in adult salmonids the pathogen commonly produces extensive necrotic lesions and named bacterial cold water disease(BCWD)(Cipriano and Holt 2005), it is 
of a serious importance due to the high fish mortality rate caused by his pathogen and the costs associated with its chemical treatment ( Nilsen et al. 2011)

Juvenile fish are primarily affected, with high mortalities in fry. It has been recognized as a worldwide occurring pathogen in freshwater aquaculture, causing substantial economic losses (Madetoja et al.2002). In very young fish, the disease can also be associated with nervous manifestations such as erratic swimming behavior and spiral movements, (Holt et al. 1993).Although outbreaks are more prevalent in winter and spring when water temperature is below $10^{\circ} \mathrm{C}$ (Nematollahiet al. 2003).

In Morocco, rainbow trout, Onchorynchusmykiss (Walbaum), farming is an important industry with 500 tons produced per year, and infection by $F$. psychrophilum has been observed in freshwater farms since 2001.

InAinaghbal fish farm, Azrou-Morocco the site of this study the eggs and young fish are incubated in filtered spring water, although this, high mortalities were documented in rainbow trout (Oncorhynchusmykiss) due to systemic bacterial cold-water disease (BCWD) in 2001.During the first month of rearing, losses of up to 72 $\%$ were observed in some batches of fish. All of these fish developed systemic BCWD within 1 to 4 wk after hatching. But there is no epidemiological study on F. psychrophilum in Morocco, despite the importance of CWD/ RTFS in local rainbow trout fisheries.

Diseases caused by this pathogen have recently become one of the most crucial problems affecting salmonid culture world wild, the disease occurs in most areas of the world including USA, Canada, Chile, Australia, Japan, Korea and several European countries (Walker and Winton 2010),

According Bernarde and Browman (2006), the adherence to the gills and intestine could be the initial stage of infection by Flavobacterium psychrofilum, Nematollahi et al in (2003), give this ability an increasing importance because it is a characteristic of virulent strains, but little is known about the pathogenesis of Flavobacterium psychrophilum.

The aim of this study was to characterize F. psychrophilum isolates obtained from CWD/ RTFS outbreaks in Morocco using biochemical, enzymatic and antimicrobial susceptibility testing.

Material and Methods

Fertilized eggs of Onchorynkus Mykiss are imported from France. Samples of diseased Rainbow trout, fertilized eggs and fry were collected from a fish hatchery in Azrou - Morocco in 2015 winter. Fries had a body weight between 20 and $100 \mathrm{~g}$.

At the time of sampling, the water temperature was noted as well as physicochemical parameters. Sampling and water temperature were the only identifiable stress factors preceding evidence of disease (Elliott 1981). For the samples $15 \mathrm{~g}$ of fertilized eggs and a total of 30 fries with and without eroded fins and/or tails were examined and taken for microbiological analyses.

The identification of $F l$. psychrophilum and laboratory diagnosis of the disease it causes istraditionally based on conventional culture on agar media and taxonomic analysis (Kritihi et al. 2017).

\section{a. Isolation and identification}

Water samples were collected in sterile flacons, fertilized eggs and fish samples were taken separately from the hatchery in sterilized sampling plastic bags, classified by age, back number and the presence of lesions or damages, they were stored in $4^{\circ} \mathrm{C}$ and transported directly to the laboratory.

In the laboratory, water samples are filtered in sterile conditions and the filters were putted in petri dishes.

For eggs $5 \mathrm{~g}$ were measured and made for centrifugation in centrifugation tubes containing $5 \mathrm{ml}$ of Cytophaga medium for $4000 \mathrm{tr} / 15 \mathrm{~min}$, before been inoculated in 10 $\mathrm{ml}$ tubes containing cytophaga brought, the tubes were placed on the incubator at $14^{\circ} \mathrm{C}$ for up to 10 days.

Fish samples taken from internal organs (liver or kidney), damaged gill tissue and, if present, skin lesions of fries body surface were streaked onto Cytophaga agar plates using sterile loops and aseptic techniques then they were directly streaked onto Cytophaga agar plates witch composed by ( $0.5 \mathrm{~g} / 1$ tryptone, $0.5 \mathrm{~g} / 1$ yeast extract, 0.2 $\mathrm{g} / \mathrm{l}$ sodium acetate, $0.2 \mathrm{~g} / \mathrm{l}$ beef extract with $9 \mathrm{~g} / \mathrm{l}$ agar, $\mathrm{pH}$ 7.2-7.4) (Anacker and Ordal. 1959) and incubated at $14^{\circ} \mathrm{C}$ for up to 10 days.

Eroded fins and tails were sampled by scraping the margin of the lesion with a sterile scalpel blade; the collected material was then inoculated onto Cytophaga agar plates and incubated at $15^{\circ} \mathrm{C}$ for up to 10 days.

After incubation period, yellow-pigmented colonies were chosen and restreaked on the Cytophaga agar to obtain pure isolates.

\section{b. Macroscopic and microscopic identification}

After isolation and purification of the suspected colonies a macroscopic characterization of each once was made for confirmation using a magnifying glass.

For the Gram straining the classical method had been followed using a young bacterial culture.

For the motility test a drop of strain's young culture is placed on a coverslip that is encircled with petroleum jelly (or any other sticky material). The coverslip and drop are then inverted over the well of a depression slide. The drop hangs from the coverslip, and the petroleum 
jelly forms a seal that prevents evaporation. Finally the covers lip is placed on a microscope slide, often is used in dark illumination to observe the motility of bacteria Koch (1878).

\section{c. Biochemical characterization}

Catalase activity was determined by the coverslip method of Taylor andAchanzar (1972) and by adding several drops of $3 \%(\mathrm{v} / \mathrm{v})$; oxidase reaction was determined by DrySlide Oxidase (Difco Laboratories, Detroit, MI, USA). Other biochemical tests were realized using the API 20E and 20NE system ®(BioMereuxVitek Hazelwood, MO). Congo red reaction was tested by the method of McCurdy (1969) using $0.01 \mathrm{mg} / \mathrm{ml}$ of a congo red solution.

Colonies have been tested for Gram staining, presence of flexirubin type pigment, cytochrome oxidase activity, catalase production and motility (Lorenzen et al. 1997). Strains witch were found to be Gram negative rod shaped, adopting gliding motility, producers of flexirubin type pigment were taken for identification and further characterization.

\section{d. Enzymatic characterization}

The ability to hydrolyze elastin and gelatin was studied by streaking each isolate on Cytophaga agar supplemented with $0.1 \%$ and $3 \%(\mathrm{w} / \mathrm{v})$ of elastin and gelatin respectively ( Krister and Wiklund. 2015); for the chitin and starch hydrolyze ability $5 \%$ of each element was add to the CA. For casein $20 \mathrm{ml}$ of sterilized skimmed milk was add to the $\mathrm{CA}$ After incubation at $15^{\circ} \mathrm{C}$ for 7 days, a positive reaction was indicated by a clear zone in the surrounding turbid agar medium around the inoculum.

\section{e. Antibiotic susceptibility test}

Antibiotic susceptibility test was performed to determine the antibiotic resistant profiles of the isolates using the KirbyBauer disc diffusion method (Bauer et al. 1966). Antibiotic discs (Oxoid, England) of neomycin $(30 \mu \mathrm{g})$, oxytetracycline $(30 \mu \mathrm{g})$, chloramphenicol, $(30 \mu \mathrm{g})$, amoxicillin $(10 \mu \mathrm{g})$, ampicillin $(10 \mu \mathrm{g})$, were used for determining the resistance profiles. Briefly, Cytophaga Broth (CB) was used to prepare bacterial suspensions. The turbidity of suspensions was adjusted as Mac Farland 0.5 and $100 \mu \mathrm{l}$ of aliquots were spread over CytophagaAgar surface. Antibiotic disks were placed on the surface of the inoculated agar plates and then they were incubated at $14^{\circ} \mathrm{C}$ for $7-10$ days. After incubationperiod, the antibiotic inhibition zone diameters were measured, evaluated and noted.

\section{RESULTS}

A total of 37isolated Gram negative, long and thin bacilli strains were isolated from samples. These isolates were then tested by some biochemical tests such as catalase, cytochrome oxidase, ONPG, H2S andglucides fermentation tests. Only 6 isolates which were found as positive for catalase and weakly positive for cytochrome oxidase, negative for ONPG, H2S Sucreoxidation/fermentation andshowed gliding movement and flexirubin type pigment production were identified as suspicious for being Flavobacteriumspp bacteria, as cited by Nakagawa and Yamasato (1996).

Table.1: Biochemical and Enzymatic characteristics of Flavobactreium psychrophilum strains isolated from Rainbow trout (Onchorhyncusmykiss) in Morocco and other strains from Europe and North America.

\begin{tabular}{|c|c|c|c|c|c|c|c|c|c|c|}
\hline \multirow[b]{2}{*}{ Strains } & \multicolumn{6}{|c|}{ winterisolates } & \multirow{2}{*}{$\begin{array}{l}\text { Pacha } \\
\text { et al } \\
1986\end{array}$} & \multirow{2}{*}{$\begin{array}{l}\text { Bernardet } \\
\text { et } \\
\text { Kerouault } \\
1989\end{array}$} & \multirow{2}{*}{\begin{tabular}{|lr|}
\multicolumn{2}{|c|}{ Lehmann } \\
et & al \\
1991 &
\end{tabular}} & \multirow{2}{*}{$\begin{array}{l}\text { Holt et } \\
\text { al } 1993\end{array}$} \\
\hline & A1N201 & A2N202 & A3N203 & A4N204 & A5N205 & A6N209 & & & & \\
\hline Oxidase & $P$ & $P$ & $\mathrm{P}$ & $\mathrm{P}$ & $\mathrm{P}$ & $\mathrm{P}$ & $\mathrm{N}$ & $\mathrm{P}$ & $\mathrm{P}$ & $\mathrm{N}$ \\
\hline Catalase & $\mathrm{P}$ & $\bar{P}$ & $\bar{P}$ & $\bar{P}$ & $\bar{P}$ & $\bar{P}$ & $P$ & $P$ & $P$ & $P$ \\
\hline Casein & $P$ & $\mathrm{P}$ & $\mathrm{P}$ & $\mathrm{P}$ & $\mathrm{P}$ & $\mathrm{P}$ & $P$ & $\mathrm{P}$ & $\mathrm{P}$ & $P$ \\
\hline Gelatin & $\mathrm{P}$ & $\mathrm{P}$ & $\mathrm{P}$ & $\mathrm{P}$ & $\mathrm{P}$ & $\mathrm{P}$ & $\mathrm{P}$ & $P$ & $P$ & $\mathrm{P}$ \\
\hline Chitin & $\mathrm{N}$ & $\mathrm{N}$ & $\mathrm{N}$ & $\mathrm{N}$ & $\mathrm{N}$ & $\mathrm{N}$ & $\mathrm{N}$ & $\mathrm{N}$ & $\mathrm{N}$ & $\mathrm{N}$ \\
\hline Congo red & $\mathrm{P}$ & $\mathrm{P}$ & $\mathrm{P}$ & $\mathrm{P}$ & $\mathrm{P}$ & $\mathrm{P}$ & - & $\mathrm{N}$ & $\mathrm{N}$ & - \\
\hline ONPG & $\mathrm{N}$ & $\mathrm{N}$ & $\mathrm{N}$ & $\mathrm{N}$ & $\mathrm{N}$ & $\mathrm{N}$ & - & $\mathrm{N}$ & $\mathrm{N}$ & - \\
\hline Lecitin & $\mathrm{N}$ & $\mathrm{N}$ & $\mathrm{N}$ & $\mathrm{N}$ & $\bar{P}$ & $\mathrm{~N}$ & $\mathrm{~N}$ & $P$ & $P$ & $\mathrm{~N}$ \\
\hline Starch & $\mathrm{N}$ & $\mathrm{N}$ & $\mathrm{N}$ & $\mathrm{N}$ & $\mathrm{N}$ & $\mathrm{N}$ & $\mathrm{N}$ & $\mathrm{N}$ & $\mathrm{N}$ & $\mathrm{N}$ \\
\hline Cit & $P$ & $P$ & $P$ & $P$ & $P$ & $P$ & - & - & - & - \\
\hline $\mathrm{H}_{2} \mathrm{~S}$ & $\mathrm{~N}$ & $\mathrm{~N}$ & $\mathrm{~N}$ & $\mathrm{~N}$ & $\mathrm{~N}$ & $\mathrm{~N}$ & $\mathrm{~N}$ & $\mathrm{~N}$ & $\mathrm{~N}$ & $\mathrm{~N}$ \\
\hline
\end{tabular}




\begin{tabular}{|l|c|c|c|c|c|c|c|c|c|c|} 
Urea & $\mathrm{N}$ & $\mathrm{N}$ & $\mathrm{P}$ & $\mathrm{N}$ & $\mathrm{N}$ & $\mathrm{N}$ & - & - & - & - \\
\hline Nitrate & $\mathrm{N}$ & $\mathrm{N}$ & $\mathrm{N}$ & $\mathrm{N}$ & $\mathrm{N}$ & $\mathrm{N}$ & $\mathrm{N}$ & $\mathrm{N}$ & $\mathrm{N}$ & $\mathrm{N}$ \\
\hline Sucre O/F & $\mathrm{N}$ & $\mathrm{N}$ & $\mathrm{N}$ & $\mathrm{N}$ & $\mathrm{N}$ & $\mathrm{N}$ & $\mathrm{N}$ & $\mathrm{N}$ & - & $\mathrm{N}$ \\
\hline G.M & $\mathrm{P}$ & $\mathrm{P}$ & $\mathrm{P}$ & $\mathrm{P}$ & $\mathrm{P}$ & $\mathrm{P}$ & $\mathrm{P}$ & $\mathrm{P}$ & $\mathrm{P}$ & $\mathrm{P}$ \\
\hline Flexirub & $\mathrm{P}$ & $\mathrm{P}$ & $\mathrm{P}$ & $\mathrm{P}$ & $\mathrm{P}$ & $\mathrm{P}$ & - & $\mathrm{P}$ & $\mathrm{P}$ & $\mathrm{P}$ \\
\hline
\end{tabular}

P: positive character / N: negative character / (- ):no data

For the antibiotic resistant profiles of our isolates, all strains were found to be sensitive to oxytetracycline with an inhibition diameter $>8 \mathrm{~mm}$ and to chloramphenicol with an inhibition diameter $>16 \mathrm{~mm}$, but resistant to ampicillin and amoxicillin with a inhibition diameter $<2 \mathrm{~mm}$ for both of them and to neomycin with a inhibition diameter $<4 \mathrm{~mm}$, disc diameter not include.

Table.2: The antibiotic resistant profiles of the isolates

\begin{tabular}{|c|c|c|c|c|c|c|}
\hline $\mathrm{ATB}_{\text {ATB }}$ Strains & A1N201 & A2N202 & A3N203 & A4N204 & A5205 & A6209 \\
\hline$\frac{\text { Néomycine }}{(30 \mu g)}$ & $\underline{\mathrm{R}}$ & $\underline{\mathrm{R}}$ & $\underline{R}$ & $\underline{\mathrm{R}}$ & $\underline{\mathrm{R}}$ & $\underline{\mathrm{R}}$ \\
\hline$\frac{\text { Oxytetracycline }}{(30 \mu \mathrm{g})}$ & $\underline{\mathrm{S}}$ & $\underline{\mathrm{S}}$ & $\underline{\mathrm{S}}$ & $\underline{\mathrm{S}}$ & $\underline{\mathrm{S}}$ & $\underline{\mathrm{S}}$ \\
\hline$\frac{\text { Chloramphenicol }}{(30 \mathrm{ug})}$ & $\underline{S}$ & $\underline{S}$ & $\underline{S}$ & $\underline{S}$ & $\underline{S}$ & $\underline{S}$ \\
\hline$\frac{\text { Amoxiciline }}{(10 \mu \mathrm{g})}$ & $\underline{\mathrm{R}}$ & $\underline{\mathrm{R}}$ & $\underline{\mathrm{R}}$ & $\underline{\mathrm{R}}$ & $\underline{\mathrm{R}}$ & $\underline{\mathrm{R}}$ \\
\hline$\frac{\text { Ampiciline }}{(10 \mu \mathrm{g})}$ & $\underline{\mathrm{R}}$ & $\underline{\mathrm{R}}$ & $\underline{\mathrm{R}}$ & $\underline{\mathrm{R}}$ & $\underline{\mathrm{R}}$ & $\underline{\mathrm{R}}$ \\
\hline
\end{tabular}

\section{DISCUSSION}

In the current study, we report isolation of Flavobacterium spp from Rainbow trout imported fertilized eggs and fries and from juveniles tanks water.Witch go with the results found by Brown et al, (1997)in their study proving that the causal agent of bacterial coldwaterdisease Flavobacterium psychrophilum istransmitted within salmonid eggs and ovarian fluid, same as Renibacteriurnsalmonjnarum, the causal agent of bacterial kidney disease, whichcould survive within salmonid eggs (Evelyn et al. 1984, Barker et al. 1991, Yousif et al. 1994). It is likely that egg transmission is a phenomenon of concern in aquaculture industry.

Data shown in this study might shed light on the potential role of the fertilized eggs importation in spreading Flavobacterium spp infection from an area to another even the difference on climate.

During the last decade, the productivity of the aquaculture industry is much intensified. Currently, it is a major economic activity in many countries (FAO. 2007). Mass production on fish farms can expose fish to stress conditions that can cause infections by pathogens including Flavobacterium psychrophilum (Wakabayashi 1991). Bacteria from flavobacterium genus are responsible for significant economic losses in salmonid culture (Nematollahi et al. 2003). That has led to increase interest in the rapid and reliable methods for detection and identification of bacterial fish pathogens (Nilsson and Strom 2002). In other side, Michel and al (1999) have reported that in some cases, isolation was not possible from infected tissues due to the presence of viable but non-cultivable cells; this was the case in our study because we got non-separated bacterial culture especially for the affected and eroded fins in fry's samples.

Phenotypically, on the modified Cytophaga agar medium our isolates produced colored colonies varied from bright yellow to orange with $2-3 \mathrm{~mm}$ in diameter with thin spreading margins. isolated strains were then identified as Flavobacterium psychrophilumspp using conventional techniques, they are Gram-negative, long bacilli, produced flexiruben upon addition of $20 \% \mathrm{KOH}$ (colonies turned brown orange), motile by gliding, very weakly catalase positive, cytochrome oxidase positive, gelatin test positive, and non-agarolytic.

Bernardet andKerouault (1989) and Holt et al (1993) note that F psychrophilum grows best in Shieh's and TYES media which suggests that medium composition is important when testing growth characteristics at the limits of the physiological range for the species, this justified our choice for the first time to work with the TYES medium, in order to limited the study to the isolation of this bacterium. 
For our strains no growth was observed on TSA plates at $15^{\circ} \mathrm{C}$ or $20^{\circ} \mathrm{C}$ or in the presence of $\mathrm{NaCl}$ concentrations above $1.5 \%$ and this is consistent with reports made by Holt et al (1993). Although Bernardet andKerouault(1989) were not able to grow their isolates in this $\mathrm{NaCl}$ concentration. The Moroccan isolates showed an optimal growth on $15^{\circ} \mathrm{C}$ and there was no growth at temperatures above $30^{\circ} \mathrm{C}$, same results were found by Bernardet and Kerouault 1989; Lehmann et al. 1991; and Holt et al. 1993.

The phonetic, biochemical and growth characters determined in this study of 6 is olates of Flavobacterium psychrophilum are in good agreement with published data for this taxon (Pacha 1968; Bernardet andKerouault 1989; Lehmann et al. 1991; Holt et al. 1993).

Performing the oxidation and/or fermentation tests using glucose as the only source of carbon revealed that the isolates were negative. They were also not able to use sucrose, starch or glucose in their basal media. Results of BioMerieuxApi 20NE rapid test strip inoculations were consistent with the biochemical reactions of Flavobacterium psychrophilum ( Cipriano and Holt 2005)

Our isolates have too many different characteristics, besides the sampling origins and seasons, we fond heterogeneity in some biochemical characters, that could be explained by the presence of too many species of Flavobacterium bacteria not only one. So to confirm which Flavobacterium specie or species are responsible of the huge lost in our hatchery a PCR analysis must be conducted.

Furthermore, it should not be ignored that unconscious use of antibiotics in fish farms may lead to inhibit the bacterial growth for the sensitive species belonging to the banal flora including Flavobacterium bacteria. Several studies have been performed to determine the antibiotic resistance profiles of Flavobacterium bacteria in various regions all over the world and quite variable profiles have been observed. (Duchaudet al.2018).

The results in the present study also showed that all strains are sensitive to chloramphenicol, some of them to oxytetracycline but they are resistant to ampicillin, amoxicillin and neomycin.

\section{CONCLUSION}

In conclusion, we report that bacteria from the Flavobacterium genus are isolated from rainbow troutimported fertilized eggs and fries for the first time in a semi-arid country, in North Africa - Morocco, we could identify them biochemically and we still need to identify them by PCR and ARN16S.

Furthermore, the long-term naturel cohabitation between clinically infected and non-infected fries or between the fries and the un-hatched eggs in the same tank or in the same water suggests a potential for the spread of Flavobacteriumspp bacteria. Because it is difficult to assess the impact of the water transmission of the infection and its subsequent effects on salmonid fish population in the fish farm in Azou-Morocco. Further work is required to characterize the virulence determinants of the Moroccan isolates and compare them with other virulent strains of Flavobacterium psychrophilum from other geographic regions.

\section{REFERENCES}

[1] Anacker R.L. and Ordal E.J. (1959). Study on the myxobacterium Chondrococcus columnaris. I. Serological typing. J Bacteriol, 78, 25-32.

[2] Austin B. and Austin, D.A. (1999). Bacterial fish pathogens: disease of farmed and wild fish. 3rd edition. Springer et Praxis Publishing Ltd., Chichester, UK.

[3] Austin B., Austin D.A. 4th ed. Praxis Publishing Ltd.; United Kingdom: 2007. Bacterial fish pathogens: diseases of farmed and wild fish.

[4] Barker GA, Smith SN, Bromage NR (1991) Commensal bacteria and their possible relationship to the mortality of Incubating salmonid eggs. J Fish Dis 14:199-210

[5] Bauer A.W., Kirby W.M., Sherris J.C. and Turck M (1966). Antibiotic susceptibility testing by a standardized single disk method. Am J Clin Pathol, 45 (4), 493-496.

[6] Bergey, D. H., F. C. Harrisson, R. S. Breed, B. W. Hammer and F. M. Huntoon (1923). Bergey's manual of determinative bacteriology, 1st ed.

[7] Bernardet J-F, Kerouault B (1989) Phenotypic and genomic studies of Cytophaga psychrophila isolated from diseased rainbow trout (Oncorhynchus mykiss) in France. Appl environ Microbial 55:1796-1800.

[8] Bernardet JP, Segers P, Vancanneyt M, Berthe F, Kersters K, Vandamme P (1996) Cutting the Gordian knot: emendedclassification and description of the genus Flavobacterium, emended description of the Family Flavobacteriaceae, and proposal of Flavobacterium hydatis nom. nov. (basonym, Cytophaga aquatills Strohl and Tait 1978). Int J Syst Bacteriol 46:128-148

[9] Cipriano RC, Holt RA. Fish disease leaflet 86. Kearneysville, WV: United States Dept. of the Interior. U.S. Geological Service, National Fish Health Research Laboratory; 2005. Flavobacterium psychrophilum, cause of Bacterial Cold-Water Disease and Rainbow Trout Fry Syndrome.

[10] Duchaud, E., Rochat, T., Habib, C., Barbier, P., Loux, V., Guérin, C., Dalsgaard, I., Madsen, L., 
Nilsen, H., Sundell, K., Wiklund, T., Strepparava, N., Wahli, T., Caburlotto, G., Manfrin, A., Wiens, G. D., Fujiwara-Nagata, E., Avendaño-Herrera, R., Bernardet, J. F., Nicolas, P. (2018). Genomic Diversity and Evolution of the Fish Pathogen Flavobacterium psychrophilum. Frontiers in microbiology, 9, 138. doi:10.3389/fmicb.2018.00138

[11] Elliot J.M. (1981). Some aspects of thermal stress on freshwater teleosts. In: Pickering AD (ed) Stress and fish. Academic Press, London, p 209-245

[12] Evelyn TPT, Prosperi-Porta L, Ketcheson JE (1984) The salmonid egg as a vector for the kidney disease bacterium Renibacterium salmoninarum. In: ACUIGRUP (ed) Fish diseases, 4th COPRAQ Session, Cadiz, Spain. Editora ATP, Madrid, p 111117

[13] Holt RA, Rohovec JS, Fryer JL (1993) Bacterial cold-water dis- ease. In: Inglis V, Roberts RJ. Bromage NR (eds) Bacterial disease

[14] Krister Sundell and Tom Wiklund (2015) Characteristics of epidemic and sporadic Flavobacterium psychrophilum sequence types. J Aquaculture; 441.doi:10.1016/j.2015.02.010.

[15] Kritihi. A, Ouaissa. K, Oumessoud. Y, Maychal. A, Barakate. M, Hasnaoui. M. 2017. Characterization of pathogenic bacteria isolated from rainbow trout (Oncorhynchus mykiss walbaum, 1792) fries in a hatchery in Azrou city (Morocco): phenotypic and biochemical studies. J. Wat. Env. Sci. Vol. 1, (S.I. COP22), 140-142.

[16] Laura L. Brown, William T. Cox , R. Paul Levine (1997) Evidence that the causal agent of bacterial coldwater disease Flavobacterium psychrophilum is transmitted within salmonid eggs. Dis Aquat Org 29: 213-218

[17] Lehmann J, Mock D, Stiirenberg F-J, Bernardet J-F (1991) First isolation of Cytophaga psychroph la from a systemic disease in eel and cyprinids. DIS aquat Org 10:217-220

[18] Lorenzen E., Dalsgaard I. and Bernardet J.F. (1997). Characterization of isolates of Flavobacterium psychrophilum associated with coldwater disease or rainbow trout fry syndrome I: Phenotypic and genomic studies. Dis Aquat Org, 31, 197-208.

[19] McCurdy HD (1969) Studies on the taxonomy of the Myxo- bacterales: I. Record of Canadian isolates and survey of methods. Can J Microbiol 15:14531461

[20] Michel C., Antonio D. and Hedrick R.P. (1999). Production of viable cultures of Flavobacterium psychrophilum approach and control. Res Microbiol, 150, 351-358.
[21] Madetoja J, Dalsgaard I, Wiklund T. Occurrence of Flavobacterium psychrophilum in fish-farming environments. Diseases of Aquatic Organisms. 2002;52(2):109-118.

[22] Nakagawa, Y. and K. Yamasato (1996). Emendation of the genus Cytophaga and transfer of Cytophaga agarovorans and Cytophaga salmonicolor to Marinilabilia gen. Nov.: phylogenetic analysis of the Flavobacterium-Cytophaga complex. Int. J. Syst. Bacteriol. 46(599-603).

[23] Nematollahı A, Decostere A, Pasmans F, Haesebrouck F (2003): Flavobacterium psychrophilum infections in salmonid fish. J Fish Dis, 26, 563-574.

[24] Nilsson WB, Strom MS (2002): Detection and identification of bacterial pathogens of fish in kidney tissue using terminal restriction fragment length polymorphism (T-RFLP) analysis of 16S rRNA genes. Dis Aquat Organ, 48, 175-185.

[25] Nilsen H, Olsen AB, Vaagnes Ø. (2011) Systemic Flavobacterium psychrophilum infection in rainbow trout Oncorhynchus mykiss (Walbaum) farmed in fresh brackish water in Norway. J Fish Dis.;34(5):403-408. doi: $\quad 10.1111 /$ j.13652761.2011.01249.x.

[26] Noga, E.J. (1996). Fish disease, diagnosis and treatment. Mosby, St Louis, Missouri.

[27] Pacha RE (1968) Characteristics of Cytophaga psychrophila (Borg) isolated during outbreaks of bacterial cold-water disease. Appl Microbiol 16:97101

[28] Taylor W.I. and Achanzar D. (1972). Catalase test as an aid to the identification of Enterobacteriaceae. Appl. Microbiol. 24:58-61.

[29] Walker, P. J., \& Winton, J. R. (2010). Emerging viral diseases of fish and shrimp. Veterinary Research, 41(6), 51. http://doi.org/10.1051/vetres/2010022.

[30] Wakabayashi H, Horinouchi M, Bunya T, Hoshiai G (1991). Outbreaks of cold-water disease in coho salmon in Japan. Fish Pathol 26:211-212.

[31] Woo, P.T.K. and Bruno, D.W. (1999). Fish diseases and disorders; volume 3: viral, bacterial and fungal infections. CABI Publishing, Oxon, UK..

[32] Yousif AN, Albright W, Evelyn TPT (1994) In vitro evidence for the antibacterilrole of lysozyrne In salmonid eggs. Dis Aquat Org 19:15-19 